\title{
Penerapan Regresi Data Panel Dinamis untuk Pemodelan Ekspor dan Impor di Asean \\ Studi Kasus di ASEAN
}

\author{
(Application of Dynamic Panel Data Regression for Export and Import Modeling in Asean) \\ Iga Amalia Yuniar ${ }^{1 *}$, Dwi Endah Kusrini ${ }^{2}$ \\ ${ }^{1,2}$ Statistika Bisnis, Fakultas Vokasi, Institut Teknologi Sepuluh Nopember (ITS) \\ Kampus ITS Sukolilo-Surabaya 60111, Indonesia \\ E-mail: iga.17106@mhs.its.ac.id, dwi_endah@statistika.its.ac.id
}

\begin{abstract}
ABSTRAK
perekonomian terbuka di suatu negara adalah negara yang mempunyai kegiatan perdagangan internasional seperti ekspor, impor, barang atau jasa serta dapat meminjam dari hasil pasar modal internasional. Tujuan dari penelitian adalah untuk menganalisis ekspor dan impor di wilayah beberapa negara ASEAN mulai periode tahun 2014 hingga tahun 2019. Metode estimasi parameter model adalah metode GMM (Generalized method of moment) karena penelitian ini menggunakan panel dinamis. Berdasarkan hasil analisis data, variabel yang berpengaruh signifikan positif terhadap model ekspor ASEAN adalah Growth GDP, REER sedangkan variabel GFCF berpengaruh secara negatif. Disamping itu, variabel yang berpengaruh siginifikan positif model impor ASEAN adalah Growth GDP dan Real Effective Exchange Rate.
\end{abstract}

Kata kunci : ASEAN, Ekspor, Impor, GMM, Data Panel Dinamis,

\begin{abstract}
Open Economy State is a state with international trading activities like goods or service export and import with also receive some loan from world capital market. States with international trading activities, especially export and import where export has important role as national ecomonic driver. Purpose of this project is to analyze export and import in ASEAN states territory during period of 2014 untill 2019. Method of estimation parameter model is GMM (Generalized method of moment) because model which used is model of dynamic data panel regression. Based on result of data analysis, variable with significant positive effect to ASEAN export model are Growth GDP and REER, while GFCF variable give negative effect. Beside that variable with significant positive effect to ASEAN import model are Growth GDP and Real Effective Exchange Rate.
\end{abstract}

Keywords : ASEAN, Expor, Import, GMM, Panel Data Dynamic

\section{PENDAHULUAN}

Perkembangan ekonomi negara saat ini masih bergantung dengan keadaan perekonomi dunia di mana suatu negara selalu ingin meningkatkan perekonomian di negaranya. Setiap negara pastinya memiliki karakteristik yang berbeda- beda dilihat dari segi hasil komoditasnya dan juga untuk mendorong hubungan ekonomi antar negara lain memerlukan adanya keterbukaan dalam hal perekonomian (Sutedi, 2014) Negara yang menganut terbukanya perekonomian merupakan negara yang memiliki ekspor dan impor barang atau jasa serta dapat meminjam dari hasil pasar modal internasional. (Mankiw, 2006). Kegiatan ekspor impor adalah bentuk suatu kegiatan untuk yang dibutuhkan oleh negera agar dapat memperkenalkan hasil karya dalam negeri di pasar internasional. (Ridha, 2019). Tujuan dari penilitian ini yaitu menganalisis model ekspor dan impor di ASEAN dengan menggunakan regresi data panel dinamis.

ASEAN merupakan organisasi yang memiliki hubungan politik dan teritori dalam lingkup nasional atau dilingkup wilayah internasional. ASEAN dibentuk untuk menciptakan suatu kerja sama, ekonomi, maupun ekonomi perdagangan dan budaya-budaya sosial yang lebih baik di antara banyak negara pada wilayah Asia Tenggara serta meningkatkan dan mengeratkan kerja sama internasional dan maupun kerja sama regional.

Dalam kasus ekonomi kebanyakan bervariabel yang dinamis, yaitu variabel yang di pengaruhi oleh variabel lain diwaktu lampau dan masa sebelumnya dari variabel tersebut. Permasalahan yang terdeteksi dari model data panel dinamis adalah terdapat korelasi error terhadap variabel lag endogen. metode OLS Akibatnya tidak dapat dilakukan regresi data panel dinamis untuk menaksir parameter karena hasil estimasi yang disebabkan nantinya estimasi tersebut tidak konsisten dan bersifat bias (Baltagi, 2005). Arellano-Bond (1991) hasil kembangan ilmu dari Anderson dan Hasio (1982) memilih metode estimasi yaitu berupa instrumental variabel dan parameter yang dihasilkan tidak efisien tetapi parameternya konsisten. Metode estimasi variabel 
instrumental ini selanjutnya dikembangkan dan diberi julukan dengan estimasi Generalized Method of Moments (GMM) untuk mendapatkan hasil parameter yang tidak bias, konsisten dan efisien. Pada penjelasan di atas, penelitian bertujuan untuk memodelkan ekspor dan impor di beberapa negara ASEAN dan menganalisis apa saja faktor yang bepengaruh tersebut.

Pada Penelitian ini menggunakan data sekunder yang diambil pada beberapa website internasional, data yang digunakan adalah data ekspor, impor, Growth GDP, Real Effective Exchange Rate (REER), dan Gross Fixed Capital Formation (GFCF). Variabel yang digunakan oleh peneliti berdasarkan rujukan yang sudah pernah dilakukan penelitian sebelumnya oleh Ruxanda \& Muraru (2010) bahwa variabel Growth GDP berpengaruh terhadap ekspor dan impor, sedangkan REER dan GFCF berpengaruh terhadap impor. Penelitian ini hanya mengambil data di Negara Brunei Darussalam, Cambodia, Indonesia, Laos PDR, Malaysia, Myanmar, Philippines, Singapore, Thailand, Vietnam (akibat keterbatasan data, Negara Timor Leste tidak dilibatkan). Batasan waktu yang digunakan selama 5 tahun, yaitu 2014 - 2019. Penelitian ini mempunyai tujuan menganalisis ekspor dan impor di wilayah beberapa negara ASEAN mulai periode tahun 2014 hingga tahun 2019

Penelitian sebelumnya pernah dilakukan oleh Ruxanda \& Muraru (2010). Penelitian tersebut digunakan sebagai rujukan untuk penelitian akhir oleh penulis. Penelitian tersebut menggunakan salah satu metode yaitu metode Three Stage Least Square (3SLS) pada model dinamis ekspor dan impor di Rumania untuk mengetahui variabel-variabel yang mempengaruhi keduanya. Berdasarkan penelitian tersebut disimpulkan bahwa hasil estimasi pada model ekspor dan impor adalah Growth GDP, REER, dan GFCF sebagai penentu utama ekspor dan impor. Jika ekspor dan impor dipengaruhi Growth GDP, maka REER dan GFCF yang berperan sebagai faktor permintaan hanya berpengaruh pada impor.

\section{METODE}

\section{Regresi Data Panel Dinamis}

Metode regresi data panel dinamis adalah suatu penerapkan metode terhadap kedinamisan pada suatu data sekarang dan mempunyai hubungan pada data sebelumnya, biasanya metode ini digunakan pada ilmu ekonomi yang bervariabel dinamis. Metode ini terdapat lag dari variabel dependen yang berfungsi untuk menjadikan variabel tersebut sebagai variabel independennya. Dalam artiannya sendiri dinamis adalah suatu nilai dari variabel yang di pengaruhi oleh nilai variabel lain dengan waktu sekarang dan yang memiliki hubungan juga dengan waktu lampau. (Arrelano dan Bond, 1991). Persamaan ini disajikan pada persamaan (1) (Arrelano \& Bond, 1991).

$$
y_{i, t}=\delta y_{i, t-1}+\boldsymbol{x}_{i, t}^{\prime} \boldsymbol{\beta}+u_{i, t} ; i=1,2, \ldots, \mathrm{N} ; t=1,2, \ldots, T
$$

Keterangan :

$y_{i, t}$ : variabel dependen pada unit cross-section ke- $i$ terhadap periode waktu $t$

$\boldsymbol{x}_{i, t}^{\prime}$ : vektor variabel independen pengamatan unit cross-section ke-i untuk periode waktu $t$ dengan berukuran $1 \times k$

$u_{i, t}:$ anggota error

$\delta$ adalah skalar, $\boldsymbol{x}_{i, t}^{\prime}$ merupakan vector dari variabel independen yang berukuran $1 \times k$. Sedangkan $\boldsymbol{\beta}$ didefinisikan sebagai vektor konstanta yang memiliki ukuran $k \times 1$. Jika diasumsikan $u_{i, t}$ merupakan one way error componen model yang didapat ditulis sebagai berikut:

$$
u_{i, t}=\mu_{i}+v_{i t}
$$

di mana $\mu_{i}$ adalah diasumsikan $\mu_{i} \sim \operatorname{IIDN}\left(0, \sigma_{\mu}^{2}\right)$ sebagai komponen error yang beespesifikasi individu dan $v_{i t}$ adalah komponen error umum yang diasumsikan $v_{i t} \sim \operatorname{IIDN}\left(0, \sigma_{v}^{2}\right)$. (Baltagi, 2005).

\section{Model Dinamis}

Model dinamis didefinisikan sebagai suatu analisis model regresi yang mempunya variabel dengan waktu saat ini dan juga bergantungg pada waktu sebelumnya. Data panel mempunyai definisi sebagai kumpulan dari data time series dan cross section (individual). Model dinamis ini merupakan model distribusi lag dan model otoregresif. Namun dalam paper ini hanya menggunakan model otoregresif. 


\section{Model Otoregresif}

Model otoregresif yaitu yang memiliki lag variabel dependennya juga pada independent variabelnya sehingga model tersebut dinyatakan sebagai model dinamis. persamaan modelnya ditunjukkan pada persamaan (2) (setiawan \& Kusrini, 2010).

$$
Y_{t} Y_{t}=\alpha+\beta_{0} X_{t}+\beta_{1} X_{t-1}+\beta_{2} X_{t-2}+\beta_{3} X_{t-3}+\gamma Y_{t-1}+\varepsilon_{t}
$$

Keterangan :

Keterangan :

$Y_{i, t-1} \quad$ : Variabel endogen eksplanatori

$\gamma \quad:$ variabel eksogen eksplanatori

$Y_{t} \quad$ : variabel dependen untuk periode waktu ke-t

$X_{t-1}$ : variabel independen untuk unit ke-i pada periode waktu ke-t- 1

$\varepsilon_{t} \quad$ : Anggota error

Persamaan model untuk dianalisis pada penelitian ini yaitu disajikan pada persamaan (3) untuk model ekspor terhadap GDP dan persamaan (4) untuk model impor terhadap GDP yang dijabarkan sebagai berikut. Model untuk Ekspor/GDP

$$
Y_{1 n t}=\varphi_{1}+\varphi_{2} X_{1 n t}+\varphi_{3} X_{2 n t}+\varphi_{4} X_{3 n t}+\varphi_{5} Y_{1 n t-1}+v_{1 n t}
$$

Model untuk Impor/GDP

$$
Y_{2 n t}=\omega_{1}+\omega_{2} X_{1 n t}+\omega_{3} X_{2 n t}+\omega_{4} X_{3 n t}
$$

untuk pengujian estimasinya akan diuji dengan pengujian estimasi GMM Arellano-Bond. Hasil estimasi ini dilakukan agar mendapatkan hasil estimasi yang efisien di mana pada persamaan panel dinamis jika menggunakan estimasi OLS menjadi tidak konsisten namun juga bias. Oleh karena itu, guna menghilangkan masalah tersebut menggunakan estimasi GMM.

\section{Estimasi Parameter GMM}

Pengestimasian untuk panel dinamis mengestimasi metode GMM. Prinsip yang digunakan oleh Arellano dan Bond (1991) adalah menggunakan GMM Arellano-Bond. Korelasi antara variabel endogen eskplanatori $\left(y_{i, t-1}\right)$ dengan error adalah definisi model data panel dinami. Beberapa dari estimasi yang telah dikembangkan, menunjukkan asumsi apa yang mendasari estimasi tersebut, seberapa baik estimasi bekerja relatif satu sama lain dan bagimana menguji validitas dari asumsi dibalik estimasi untuk memilih estimasi yang paling sesuai untuk data yang digunakan dalam penelitian. (Wawro, 2002).

\section{Metode Generalized Method of Moment}

Metode estimasi Generalized Method of Moment ini nantinya akan menjadi sebuah model yang estimasinya tidak bias, konsisten serta efisien. Berikut ini hasil estimasinya.

$$
\begin{aligned}
& \left(\begin{array}{l}
\hat{\delta} \\
\hat{\beta}
\end{array}\right)=\left[\left(N^{-1} \sum_{i=1}^{N}\left(\Delta \boldsymbol{y}_{i, t-1}, \Delta_{x i}\right)^{\prime} \boldsymbol{Z}_{\boldsymbol{i}}\right) \widehat{\boldsymbol{W}}\left(N^{-1} \sum_{i=1}^{N} \boldsymbol{Z}_{\boldsymbol{i}}^{\prime}\left(\Delta \boldsymbol{y}_{i, t-1}, \Delta_{\boldsymbol{x} i}\right)\right)\right]^{-1} \\
& {\left[\left(N^{-1} \sum_{i=1}^{N}\left(\Delta \boldsymbol{y}_{i, t-1}, \Delta_{x i}\right)^{\prime} \boldsymbol{Z}_{\boldsymbol{i}}\right) \widehat{\boldsymbol{W}}\left(N^{-1} \sum_{i=1}^{N} \boldsymbol{Z}_{\boldsymbol{i}}^{\prime} \Delta \boldsymbol{y}_{\boldsymbol{i}}\right)\right]}
\end{aligned}
$$

$\boldsymbol{Z}_{\boldsymbol{i}}$ : Matriks instrumen yang valid

$\widehat{\boldsymbol{W}}$ : Estimasi tidak bias dan konsisiten untuk $\boldsymbol{W}_{(\boldsymbol{L} \boldsymbol{x} \boldsymbol{L})}$ dengan $L$ adalah jumlah variabel instrumen

Untuk mengetahui hasil two step estimator dengan cara mensubtitusikan bobot $\widehat{\boldsymbol{W}}$ dengan $\widehat{\boldsymbol{\Lambda}}^{-1}$ dengan :

$\widehat{\Lambda}^{-1}=N^{-1} \sum_{i=1}^{N} Z_{i}^{i} \Delta v_{i} \Delta v_{i}^{i} Z_{i}$

sehingga hasil estimasinya menjadi sebagai berikut

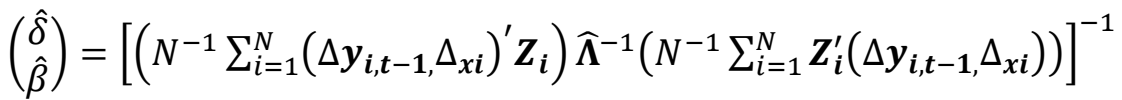

$$
\begin{aligned}
& {\left[\left(N^{-1} \sum_{i=1}^{N}\left(\Delta \boldsymbol{y}_{i, t-1}, \Delta_{x i}\right)^{\prime} \boldsymbol{Z}_{\boldsymbol{i}}\right) \widehat{\boldsymbol{\Lambda}}^{-1}\left(N^{-1} \sum_{i=1}^{N} \boldsymbol{Z}_{\boldsymbol{i}}^{\prime} \Delta \boldsymbol{y}_{\boldsymbol{i}}\right)\right]}
\end{aligned}
$$

\section{Uji Spesifikasi Model}

Uji spesifikasi model merupakan pengujian konsistensi estimasi yang diperoleh terhadap hasil analisis GMM Arellano-Bond dan juga untuk mengetahui kevalidan dari variabel instrument yang mempunyai insturmennya melebihi jumlah parameter yang diduga. Metode yang digunakan adalah dengan (Shina, 2015). 


\section{Ekspor dan Impor}

Ekspor adalah perdagangan skala internasional yang menyebabkan adanya permintaan negara itu sendiri sehingga tumbuhnya industri-industri pabrik besar, lembaga sosial yang fleksibel, dan, struktur politik yang stabil untuk suatu negara yang melakukan perdagangan. (Todaro dan Michael, 2000). Berdasarkan definisi tersebut, kegiatan ekspor suatu negara bertujuan untuk menstabilkan peningkatan pendapatan suatu negara. Apabila pengeluaran agregat meningkat dengan tinggi maka akan meningkatkan kegiatan ekspor dan selanjutnya pendapatan di negara tersebut akan meningkat pula (Saeroji, 2011).

\section{Data dan Sumber Data}

Data untuk diolah sebagai hasil analisis pada penelitian ini adalah data sekunder di beberapa negara ASEAN tahun 2014-2019. Data ini diperoleh dari publikasi data World Bank dan data Asian Statistics. Tautan untuk memperoleh data dapat diakses di website https://www.aseanstats.org/ dan https://data.worldbank.org/. Pengambilan data dilakukan pada tanggal 23 Desember 2020. Unit penelitian ini yang digunakan yaitu 10 negara di ASEAN, digunakan data dari tahun 2014 hingga 2019. Beberapa negara yaitu Negara Brunei Darussalam, Kamboja, Indonesia, Laos, Malaysia, Myanmar, Filipina, Singapura, Thailand, dan Vietnam.

\section{Identifikasi Variabel}

Variabel penelitian untuk pemodelan ekspor impor Negara-negara di ASEAN ditunjukkan pada Tabel 1.

Tabel 1 Variabel Penelitian

\begin{tabular}{cclc}
\hline Notasi & Variabel & Skala & Satuan \\
\hline$Y_{1 \mathrm{nt}}$ & Ekspor/GDP & Rasio & Presentase (\%) \\
$Y_{2 \mathrm{nt}}$ & Impor/GDP & Rasio & Presentase (\%) \\
$X_{1 \mathrm{nt}}$ & Growth GDP & Rasio & Presentase (\%) \\
$X_{2 \mathrm{nt}}$ & REER (Real Effective Exchange Rates) & Rasio & Presentase (\%) \\
$X_{3 \mathrm{nt}}$ & GFCF (Gross Fixed Capital Formation) & Rasio & Presentase (\%) \\
\hline
\end{tabular}

\section{Langkah Analisis Model}

Langkah analisis data untuk tercapainya tujuan dalam penelitian ini adalah sebagai berikut.

a. Melakukan estimasi parameter menggunakan metode GMM

b. Melakukan uji serentak dengan memakai uji Wald.

c. Menguji parsial terhadap parameter model yang diperoleh dari hasil uji $t$.

d. Menguji Spesifikasi model menggunakan analisis uji Arellano-Bond dan Sargan.

e. Melakukan interpretasi pada model dengan metode GMM.

f. Melakukan uji asumsi klasik.

g. Menarik kesimpulan dari hasil analisis.

\section{HASIL DAN PEMBAHASAN}

Signifikansi parameter diuji menggunakan uji serentak dan uji parsial pada data pemodelan ekspor, impor di beberapa negara ASEAN dengan model regresi data panel dinamis..

Berdasarkan hasil estimasi secara serentak didapatkan nilai $\chi_{\text {hitung }}^{2}$ sebesar 83,390 lebih besar dari nilai $\chi_{\text {tabel }}^{2}$ sebesar 2,705 serta $P$-valuenya adalah 0,0000 di mana $>\alpha$ sebesar 0,1 , dengan hasil tersebut diperoleh keputusan tolak $H_{0}$ yang berarti paling tidak ada satu koefisien yang berpengaruh signifikan terhadap model.

Setelah uji serentak, berikutnya uji parameter secara parsial untuk mengetahui pengaruh signifikansi nilai koefisien pada model. Pengujiannya tercantum pada Tabel 1.

Tabel 1 menyajikan bahwa hasil uji parsial, berdasarkan hasil tersebut dengan tingkat kesalahan $\alpha$ sebesar 0,1 didapatkan variabel $\mathrm{X}_{1}$ (Growth GDP), variabel $\mathrm{X}_{2}(\mathrm{GFCF})$, dan variabel $\mathrm{X}_{3}$ (REER) mendapatkan hasil bahwa $t_{h i t}$ lebih besar dari nilai $t_{\text {tabel }}(1,305)$, sehingga diperoleh keputusan tolak $H_{0}$ yang berarti variabel $\mathrm{X}_{1}$ (Growth GDP), $\mathrm{X}_{2}$ (GFCF), dan variabel $\mathrm{X}_{3}$ (REER) berpengaruh signifikan terhadap model. Disamping itu, variabel $\mathrm{Y}_{1(-1)}$ (lag ekspor) memiliki nilai $t_{\text {hit }}$ lebih kecil dari nilai $\mathrm{t}_{\text {tabel }}(1,305)$, keputusan yang didapatkan adalah gagal tolak $H_{0}$ yang berarti variabel $\mathrm{Y}_{1(-1)}$ (lag ekspor) tidak berpengaruh signifikan terhadap model. 
Tabel 1 Estimasi Parameter Secara Parsial

\begin{tabular}{ccccc}
\hline Variabel & Koefisien & Std Error & Uji Statistik & $P$-Value \\
\hline Y1(-1) & 0,089406 & 0,047083 & 1,898890 & 0,0656 \\
X1 & 1,667131 & 0,182562 & 9,131842 & 0,0000 \\
X2 & $-0,644954$ & 0,130610 & $-4,938020$ & 0,0000 \\
X3 & 132,7223 & 21,06358 & 6,301033 & 0,0000 \\
\hline
\end{tabular}

Pengujian selanjutnya adalah pengujian signifikansi parameter untuk model impor. Berdasarkan hasil estimasi parameter secara serentak dengan diperoleh hasil $\chi_{\text {hitung }}^{2}$ sebesar 19,338 yang dimana lebih tinggi dari nilai $\chi_{\text {tabel }}^{2}$ sebesar 2,705 serta nilai $P$-Value sebesar 0,000 yang dimana kurang dari $\alpha$ sebesar 0,1 . Oleh karena itu diperoleh keputusan tolak $H_{0}$ yang berarti bahwa paling tidak ada satu koefisien yang berpengaruh signifikan terhadap model. Selanjutnya adalah hasil estimasi secara parsial yang disajikan pada Tabel 2.

Tabel 2 Estimasi Parameter Secara Parsial

\begin{tabular}{ccccc}
\hline Variabel & Koefisien & Std Error & Uji Statistik & $P$-Value \\
\hline $\mathrm{Y}_{2(-1)}$ & 0,296688 & 0,067466 & 4,397572 & 0,0001 \\
$\mathrm{X}_{1}$ & 2,372230 & 0,275279 & 8,617535 & 0,0000 \\
$\mathrm{X}_{2}$ & $-0,214877$ & 0,458399 & $-0,468755$ & 0,6421 \\
$\mathrm{X}_{3}$ & 148,4456 & 26,08166 & 5,691573 & 0,0000 \\
\hline
\end{tabular}

Tabel 2 menunjukkan hasil uji parsial variabel yang berpengaruh ke model. Berdasarkan uji signifikansi parsial dengan tingkat kesalahan $\alpha$ sebesar 0,1 diperoleh hasil bahwa variabel $\mathrm{X}_{1}$ (Growth GDP) dan variabel $\mathrm{X}_{3}$ (REER) memiliki nilai $\mathrm{t}_{\text {hit }}$ lebih tinggi dari nilai $\mathrm{t}_{\text {tabel }}(1,305)$ artinya tolak $H_{0}$ maka variabel $\mathrm{X}_{1}($ Growth GDP), variabel $X_{3}$ (REER), dan variabel $\mathrm{Y}_{2(-1)}$ (lag ekspor) berpengaruh signifikan terhadap model. Disamping itu, variabel $\mathrm{X}_{2}(\mathrm{GFCF})$ memiliki nilai $\mathrm{t}_{\text {hit }}$ kurang dari nilai $\mathrm{t}_{\text {tabel }}(1,305)$, sehingga diperoleh keputusan gagal tolak $H_{0}$ yang berarti variabel $\mathrm{X}_{2}(\mathrm{GFCF})$ tidak berpengaruh signifikan terhadap model.

Hasil analisis menunjukkan bahwa variabel $\mathrm{X}_{2}$ yaitu variabel GFCF tidak berpengaruh signifikan, maka perlu dilakukan pengujian kembali menggunakan uji serentak dan uji parsial untuk menentukan model terbaik berdasarkan variabel-variabel yang signifikan. Setelah proses pemodelan ulang diperoleh variabel yang berpengaruh signifikan yaitu variabel $\mathrm{X}_{1}$ (Growth GDP) dan variabel $\mathrm{X}_{3}$ (REER) serta variabel $\mathrm{Y}_{2(-1)}$ (lag ekspor) yang dijelaskan sebagai berikut.

Hasil pengujian berdasarkan estimasi serentak hasil analisis didapatkan $\chi_{\text {hitung }}^{2}$ sebesar 5,0941 lebih dari nilai $\chi_{\text {tabel }}^{2}$ sebesar 2,705 serta nilai $P$-Valuenya 0,0240 di mana $>\alpha$ sebesar 0,1 , jadi diperoleh keputusan tolak $H_{0}$ berarti paling tidak ada satu koefisien yang mempengaruhi model secara signifikan. Berikut adalah hasil estimasi secara parsial yang disajikan pada Tabel 3.

Tabel 3 Estimasi Parameter Secara Parsial

\begin{tabular}{ccccc}
\hline Variabel & Koefisien & Std Error & Uji Statistik & $P$-Value \\
\hline $\mathrm{Y}_{(-1)}$ & 0,136407 & 0,060437 & 2,257028 & 0,0300 \\
$\mathrm{X}_{1}$ & 2,121034 & 0,220930 & 9,600492 & 0,0000 \\
$\mathrm{X}_{3}$ & 183,1283 & 27,96192 & 6,549205 & 0,0000 \\
\hline
\end{tabular}

Tabel 3 menunjukkan hasil uji parsial yang berpengaruh terhadap model. Berdasarkan hasil tersebut diperoleh hasil bahwa variabel $\mathrm{X}_{1}$ (Growth $\mathrm{GDP}$ ), variabel $\mathrm{X}_{3}$ (REER) dan variabel $\mathrm{Y}_{2(-1)}$ (lag ekspor) memiliki nilai $t_{\text {hit }}$ lebih dari nilai $\mathrm{t}_{\text {tabel }}(1,305)$, sehingga diperoleh keputusan tolak $H_{0}$ yang berarti variabel $\mathrm{X}_{1}($ Growth GDP), variabel $\mathrm{X}_{3}$ (REER), dan variabel $\mathrm{Y}_{2(-1)}$ (lag impor) mempengaruhi model secara signifikan.

Setelah mendapatkan model terbaik, selanjutnya dilanjutkan dengan analisis uji Sargan untuk model ekspor beberapa negara ASEAN pada Tabel 4.

Tabel 4 Uji Sargan Data Ekspor

\begin{tabular}{ccc}
\hline Pengujian & Nilai Statistik & $P$-Value \\
\hline Uji Sargan & 4,295334 & 0,5354 \\
\hline
\end{tabular}

Tabel 4 dapat diketahui bahwa hasil uji Sargan adalah 4,29533 lebih kecil dari $\chi_{\text {tabel }}^{2}$ sejumlah 2,705 dan diperkuat dengan $P$-Valuenya 0,5354 lebih kecil $\alpha=0,1$, diputuskan adalah gagal tolak $H_{0}$ yang artinya tidak ada variabel instrumen yang berkorelasi dengan error jadi variabel instrumennya valid. 
Langkah selanjutnya yaitu hasil analisis uji Arellano-Bond. Berikut dijelaskan hasil uji Arellano-Bond untuk model ekspor beberapa negara ASEAN pada Tabel 5.

Tabel 5 Uji Arellano-Bond Data Ekspor

\begin{tabular}{ccc}
\hline Pengujian & Nilai Statistik & $P$-Value \\
\hline $\operatorname{AR}\left(m_{1}\right)$ & 0,503396 & 0,6147 \\
$\operatorname{AR}\left(m_{2}\right)$ & $-0,011354$ & 0,9909 \\
\hline
\end{tabular}

Tabel 5 dapat bahwa Hasil Arellano-Bond dengan nilai statistik $m_{l}$ sebesar 0,5033 lebih kecil dari $Z_{\alpha / 2}$ sebesar 1,28 dan diperkuat dengan nilai $P$-Value 0,6147 tidak signifikan terhadap $\alpha$ sebesar 0,1 persen. Berarti nilai statistik $m_{2}$ pada uji Arellano-Bond adalah -0,0113 lebih kecil dari $Z_{\alpha / 2}$ sebesar 1,28 dan diperkuat dengan nilai $P$-Value sebesar 0,9909 , sehingga gagal tolak $H_{0}$ artinya tidak terdapat autokorelasi pada sisaan first difference orde ke- $i$

Langkah berikut untuk uji Sargan untuk model impor beberapa negara ASEAN pada Tabel 6.

Tabel 6 Uji Sargan Data Impor

\begin{tabular}{ccc}
\hline Pengujian & Nilai Statistik & $P$-Value \\
\hline Uji Sargan & 5,122446 & 0,645023 \\
\hline
\end{tabular}

Tabel 6 dapat diketahui bahwa hasil uji Sargan 5,1224 lebih kecil dari $\chi_{\text {tabel }}^{2} 2,705$, diperkuat dengan $P$ Valuenya 0,6450 lebih kecil dari $\alpha=0,1$, diputuskan adalah gagal tolak $H_{0}$ artinya tidak ada variabel instrumen yang berkorelasi dengan error jadi variabel instrumennya sudah valid.

Berikut Hasil analisis uji Arellano-Bond yang bertugas untuk mengetahui estimasi yang konsisten yaitu tidak ada autokorelasi antara residuan dengan variabel endogen dimana ditunjukkan melalui first diffence orde ke-2. Berikut dijelaskan hasil uji Arellano-Bond untuk model ekspor beberapa negara ASEAN pada Tabel 7.

Tabel 7 Uji Arellano-Bond Data Impor

\begin{tabular}{ccc}
\hline Pengujian & Nilai Statistik & P-Value \\
\hline $\operatorname{AR}\left(m_{1}\right)$ & $-1,235083$ & 0,2168 \\
$\operatorname{AR}\left(m_{2}\right)$ & $-0,15355$ & 0,878 \\
\hline
\end{tabular}

Tabel 7 didapatkan hasil Arellano-Bond dengan nilai statistik $m_{l}-1,2350$ lebih kecil dari $Z_{\alpha / 2}$ sebesar 1,28 dan diperkuat dengan nilai $P$-Valuenya 0,2168 tidak signifikan untuk $\alpha$ sebesar 0,1 persen. Hasil estimasi nilai statistik $m_{2}-0,1535$ lebih kecil dari $Z_{\alpha / 2}$ sebesar 1,28 dan diperkuat dengan nilai $P$-Value sebesar 0,8780, sehingga gagal tolak $H_{0}$ bahwa tidak terdeteksi adanya autokorelasi terhada sisaan first difference orde ke- $i$.

Tabel 1 dan Tabel 3 dapat dihasilkan model yang didapat untuk model eskpor dan model impor adalah pada persamaan sebagai berikut.

Model ekspor

$Y_{1 n t}=1,667 X_{1 n t}-0,6444 X_{2 n t}+132,722 X_{3 n t}+0,089 Y_{1 n t-1}+v_{1 n t}$

Model impor

$Y_{2 n t}=2,121 X_{1 n t}+183,128 X_{3 n t}+0,136 Y_{2 n t-1}+v_{2 n t}$

Sesudah diketahuinya model tersebut, selanjutnya modeo tersebut digunakan untuk mendapatkan nilai elastisitas jangka panjang dan jangka pendeknya. Adapun nilai estimasi) jangka untuk model Ekspor dan impor akan dijelaskan sebagai berikut.

Tabel 8 Pengaruh Jangka Pendek dan Jangka Panjang Model Ekspor

\begin{tabular}{ccc}
\hline \multirow{2}{*}{ Variabel Prediktor } & \multicolumn{2}{c}{ Koefisien } \\
\cline { 2 - 3 } & Jangka Pendek & Jangka Panjang \\
\hline Growth GDP & 0,032088 & 0,0327 \\
GFCF & $-0,271253$ & $-0,2766$ \\
REER & 0,727044 & 0,7414 \\
Ekspor(-1) & 0,0194 & - \\
\hline
\end{tabular}

Tabel 8 maka interpretasi pengaruh jangka pendek dan jangka panjangnya dari model Ekspor beberapa negara ASEAN adalah sebagai berikut.

Hubungan antara koefisien elastisitas dari Growth GDP dengan ekspor berhubungan positif. Sehingga jika Growth GDP meningkat maka akan menghasilkan nilai yang positif pada nilai ekspor. Nilai koefisien 
elastisitas Growth GDP dalam jangka pendek bernilai 0,0320 artinya setiap nilai Growth GDP bertambah sebanyak $1 \%$, nilai ekspor akan meningkat $0,032 \%$ dengan mengasumsikan nilai variabel GFCF dan REER tetap. Sedangkan dalam jangka panjang nilai koefisien elastisitas Growth GDP sebesar 0,0327, artinya setiap kenaikan nilai Growth GDP sebanyak 1\% dengan meningkatnya ekspor sebanyak 0,0327\% dengan diasumsikan bahwa nilai variabel GFCF dan REER tetap.

Hubungan antara nilai koefisien elastisitas dari GFCF dengan ekspor berhubungan negatif. Hal ini menyebabkan bahwa GFCF yang menurun akan bernilai negatif pada nilai ekspor. Nilai koefisien elastisitas GFCF dalam jangka pendek bernilai 0,2712, artinya setiap nilai koefisien GFCF bertambah sebesar 1\%, maka akan menurunkan nilai ekspor sebesar 0,2712\% dengan asumsi bahwa nilai Growth GDP, REER bernilai tetap. Nilai untuk koefisien elastisitas GFCF dalam jangka sebesar 0,2766, artinya setiap nilai GFCF bertambah sebesar $1 \%$, nantinya akan menurunkan nilai ekspor secara sebesar $0,2766 \%$ dengan diasumsikan bahwa nilai Growth GDP dan REER bernilai tetap.

Hasil tersebut telah dilakukan juga oleh Basuki (2018) di mana hasil penelitian yang didapatkan bahwa hasil estimasi jangka pendek menunjukkan bahwa variabel GFCF pada lag 1 mempunyai pengaruh negatif terhadap variabel perdagangan, yang artinya jika GFCF mengalami kenaikan sejumlah $1 \%$ pada tahun sebelumnya, maka akan nilai dari perdagangan akan menurun pada tahun sekarang. Sedangkan hasil estimasi jangka panjang menunjukkan untuk GFCF yang bernilai lag 1 mempengaruhi secara negatif dan bersignifikansi ke trade, yaitu sebanyak -1,321. Mengartikan bahwa jika GFCF mengalami kenaikan yang signifikan sebanyak $1 \%$ pada periode lampau, berdampak terjadinya penurunan trade sebanyak $-1,321$ persen (Basuki, 2018).

Hubungan antara nilai koefisien elastisitas REER dengan nilai Persentase ekspor mempunyai hubungan yang positif. Artinya jika nilai REER yang mengalami peningkatan maka akan menghasilkan nilai ekspor yang positif. Nilai koefisien elastisitas REER dalam jangka pendek bernilai 0,7270, artinya setiap koefisien elastisitas REER meningkat sebanyak 1\%, sehingga nilai ekspor akan mengalami kenaikan berupa nilai $0,7270 \%$ maka diasumsikan bahwa variabel Growth GDP dan GFCF mempunyai nilai tetap. Dalam jangka panjang nilai koefisien elastisitas REER sebesar 0,7414, artinya setiap REER mengalami kenaikan sebanyak $1 \%$, maka nilai ekspor meningkat sebesar $0,7414 \%$ dengan diasumsikan bahwa Growth GDP dan GFCF bernilai tetap.

Tabel 9 Pengaruh Jangka Pendek dan Jangka Panjang Model Impor

\begin{tabular}{ccc}
\hline Variabel & \multicolumn{2}{c}{ Koefisien } \\
\cline { 2 - 3 } & Jangka Pendek & Jangka Panjang \\
\hline Growth GDP & 0,098382 & 0,23538 \\
REER & 0,029048 & 0,06950 \\
Impor(-1) & 0.582045 & - \\
\hline
\end{tabular}

Tabel 9 menyajikan hasil adanya pengaruh jangka panjang maupun jangka pendek pada model impor beberapa negara ASEAN dengan interpretasinya sebagai berikut.

Hubungan antara koefisien elastisitas dari Growth GDP dengan impor berhubungan positif. Artinya jika nilai Growth GDP meningkat maka akan berpengaruh positif pada nilai impornya. Nilai koefisien elastisitas Growth GDP dalam jangka pendek bernilai 0,098, artinya setiap nilai Growth GDP bertambah sebanyak 1\%, sehingga nilai ekspor bertambah sebesar $0,098 \%$ dengan asumsi bahwa nilai dari REER konstan. Sedangkan dalam jangka panjang nilai koefisien elastisitas Growth GDP sebanyak 0,235, artinya setiap kenaikan nilai Growth GDP sebesar 1\%, maka nilai impor meningkat sebanyak 0,235\% dengan diduga bahwa nilai REER konstan.

Hubungan antara nilai dari koefisien elastisitas REER dengan nilai Persentase impor berhubungan positif. Sehingga nilai REER yang meningkat akan mempunyai positif pada nilai impor. Nilai koefisien elastisitas REER dalam jangka pendek bernilai 0,0290, artinya setiap koefisien elastisitas REER bertambah sebanyak $1 \%$, dan nilai ekspor mengalami peningkatan sebanyak 0,0290\% dengan dugaan bahwa nilai Growth GDP bernilai konstan. Sedangkan dalam jangka panjang nilai koefisien elastisitas REER sebesar 0,0695 artinya setiap koefisien elastisitas REER sebanyak 1\%, nilai ekspor akan bertambah sebanyak 0,0695\% dengan dugaan bahwa Growth GDP bernilai tetap.

Nilai Real Effective Exchange Rate (REER) mengalami kenaikan maka berdampak mahalnya nilai ekspor dan nilai impor menjadi lebih murah. Dengan peningkatan maka akan mengurangi persaingan pada pedagangan. kemudian dilakukan uji asumsi klasik dari residual model yang terdiri dari uji heteroskesdastisitas dan uji autokorelasi. Berikut uji asumsi autokorelasi, heteroskedastisitas, dan uji normalitas untuk model eskpor sebagai berikut. 
Untuk uji homokedastisitas pada data residual untuk model ekspor yaitu menggunakan uji Sargan dengan hasil uji asumsi klasiknya di tunjukkan pada Tabel 10 berikut.

Tabel 10 Uji Heteroskedastisitas

\begin{tabular}{ccc}
\hline Pengujian & Nilai Statistik & $P$-Value \\
\hline Uji Heteroskedastisitas & 4,2953 & 0,63677 \\
\hline
\end{tabular}

Tabel 10 didapatkan hasil uji heteroskesdastisitas sebesar 4,2953 kurang dari $\chi_{\text {tabel }}^{2}$ sebesar 2,705 dan diperkuat dengan $P$-Value sebesar 0,6367 kurang dari nilai $\alpha=0,1$, sehingga diputuskan tidak terdeteksi heteroskedastisitas pada model ekspor atau residual estimasi GMM terhada model ekspor bersifat homogen atau identik.

Pengujian asumsi autokorelasi pada data residual model ekspor dijelaskan pada Tabel 11.

Tabel 11 Uji Autokorelasi

\begin{tabular}{ccc}
\hline Pengujian & Nilai Statistik & $P$-Value \\
\hline Uji Autokorelasi & $-0,011354$ & 0,9909 \\
\hline
\end{tabular}

Tabel 11 diketahui nilai uji autokorelasi sebanyak 0,011354. Dengan tingkat kesalahan $\alpha 0,1$, maka nilai autokorelasi model lebih kecil dari nilai $Z_{\text {tabel }}(1,96)$ dan dikuatkan dengan $P$-Value $0,9909>\alpha$ sebesar 0,1 , sehingga diputuskan terdeteksi tidak ada autokorelasi sehingga estimasi GMM Arellano-Bond telah independen.

Berikut hasil uji heteroskesdastisita, uji asumsi klasik autokorelasi, dan uji normalitas untuk model impor yang ditunjukkan sebagai berikut.

Hasil uji asumsi klasik untuk pengujian heteroskedastisitas dapat di tunjukkan pada Tabel 12.

Tabel 12 Uji Heteroskedastisitas

\begin{tabular}{ccc}
\hline Pengujian & Nilai Statistik & $P$-Value \\
\hline Uji Heteroskedastisitas & 5,052404 & 0.653568 \\
\hline
\end{tabular}

Tabel 12 dapat diketahui bahwa hasil nilai 5,0524 yang dihasilkan dari uji heteroskesdastisitas lebih kecil dari $\chi_{\text {tabel }}^{2}$ sebesar 1,305 dan dikuatkan $P$-Value 0,6535 lebih kecil dari nilai $\alpha=0,1$, sehingga diputuskan tidak terdeteksi heteroskedastisitas pada model impor atau residual model GMM tersebut pada model impor bersifat homogen atau identik.

Uji asumsi autokorelasi pada data residual untuk model impor dijelaskan pada Tabel 13.

Tabel 13 Uji Autokorelasi

\begin{tabular}{ccc}
\hline Pengujian & Nilai Statistik & $P$-Value \\
\hline Uji Autokorelasi & $-0,15355$ & 0,8780 \\
\hline
\end{tabular}

Tabel 13 diketahui nilai uji autokorelasi sebanyak-0,1535. Dengan tingkat kesalahan $\alpha$ sebanyak 0,1 , maka nilai autokorelasi model lebih kecil dari nilai $\mathrm{Z}_{\text {tabel }}(1,96)$ dan dikuatkan nilai $P$-Value sebesar 0,8780 lebih kecil dari $\alpha$ sehingga kesimpulannya tidak terdeteksi autokorelasi sehiingga model GMM Arellano-Bond telah independen.

Uji asumsi klasik normalitas dilakukan untuk menguji residual dari model telah memenuhi asumsi distribusi normal atau tidak. Uji asumsi ini dengan dilakukannya pengujian oleh uji Jarque-Bera. Hasil analisis uji normalitas dijelaskan pada Tabel 14 .

Tabel 14 Uji Normalitas

\begin{tabular}{ccc}
\hline Pengujian & Statistik Uji & $P$-Value \\
\hline Normalitas & 0,088194 & 0,956861 \\
\hline
\end{tabular}

Tabel 14 menunjukkan hasil bahwa nilai statistik uji normalitas diperoleh dari nilai Jarque-Bera test adalah 0,0881 lebih kecil dari nilai $\chi_{(0,1,1)}^{2}$ sebesar 5,9914 dan diperkuat dengan $P$-Value 0,956861 lebih dari nilai $\alpha$ $=0,1$, jadi diputuskan gagal tolak $H_{0}$ yang berarti bahwa residual data untuk model impor berdistribusi normal. 


\section{KESIMPULAN}

Didapatkan model dengan estimasi first difference GMM Arellano-Bond didapatkan tiga signifikansi variabel yang berpengaruh pada model ekspor, yaitu variabel growth GDP, variabel Gross Fixed Capital Formation, dan variabel Real Effective Exchange Rate dengan model sebagai berikut.

$$
Y_{1 n t}=1,667 X_{1 n t}-0,6444 X_{2 n t}+132,722 X_{3 n t}+0,089 Y_{1 n t-1}+v_{1 n t}
$$

Efek jangka pendek dan jangka panjang dapat diketahui dari hasil analisis tersebut dari masing-masing variabel signifikan yang terhadap model. Variabel yang mendapatkan nilai elastisitas jangka panjang tertinggi terhadap model ekspor adalah variabel REER sebesar 0.7414. Selain itu model juga sudah memenuhi uji asumsi klasik heteroskedastisitas dan autokorelasi. Model impor diketahui 2 variabel yaitu variabel Growth GDP dan variabel Real Effective Exchange Rate yang berpengaruh secara signifikan kepada model sebagai berikut.

$$
Y_{2 n t}=\omega_{1}+2,1210 X_{1 n t}+183,1283 X_{3 n t}+0,136407 Y_{2 n t-1}+v_{2 n t}
$$

Pada model impor tersebut diketahui variabel yang mempunyai hasil tertinggi untuk elastisitas jangka panjang terhadap model impor adalah variabel Growth GDP sebesar 0.2353. Selain itu model sudah memenuhi uji asumsi klasik heteroskedastisitas, autokorelasi, dan normalitas.

\section{DAFTAR PUSTAKA}

Arellano, M., \& Bond, S. (1991). Some Test of Spesification for Panel Data : Monte Carlo Evidence and an Applicationcc to Employment Equations. The Review of Economic Studies, Vol. 58: 277-297.

Mankiw, N. G. (2006) “ Makroekonomi”. Terjemahan oleh Fitria dan imam. Jakarta: Erlangga.

Ridha, M., Indra, \& Safrida. (2019). Faktor-Faktor Yang Mempengaruhi Ekspor Lada. Jurnal Ilmiah Mahasiswa Pertanian, 4(1), 387-400.

Ruxanda, G., \& Muraru, A. (2010). Fdi And Economic Growth.Evidence From Simultaneous Equation Models. Romanian Journal of Economic Forecasting

Saeroji, A. F. (2011). Analisis Determinan Ekspor Karet Alam Ke Amerika Serikat 1981 - 2010 ( Dengan Pendekatan Partial Adjusment Model ) (Vol. 2010).

Shina, A. F. (2015). Penerapan Generalized Method of moment Arellano-Bond Estimator pada Persamaan Simultan Data Panel Dinamis untuk Pemodelan Pertumbuhan Ekonomi Indonesia. Jurusan Statistika. Surabaya: Thesis Jurusan Statistika FMIPA-ITS

Setiawan \& Kusrini,D.E. (2010). Ekonometrika. Yogyakarta: C.V Andi Offset

Sutedi, A., (2014). Hukum Ekspor Impor. Raih Asa Sukses ed. Jakarta: Penebar Swadaya Grup.

Todaro \& Michael, P., (2000). Pembangunan ekonomi di dunia ketiga. edisi ketujuh ed. jakarta: Erlangga.

Wawro, G. (2002). Estimating Dynamic Panel Data Models in Political Science. Political Analysis, 10(1), 2548. https://i.org/10.1093/pan/10.1.25 